\title{
Developing student's metacognitive ability in science through project-based learning with e-portfolio
}

\author{
Marheny Lukitasari ${ }^{1}$, Rusdi Hasan ${ }^{2}$, Akhmad Sukri $^{3}$, Jeffry Handhika ${ }^{4}$ \\ ${ }^{1}$ Department of Biology Education, Universitas PGRI Madiun, Indonesia \\ ${ }^{2}$ Department of Biology Education, Universitas Muhammadiyah Bengkulu, Indonesia \\ ${ }^{3}$ Department of Biology Education, Universitas Pendidikan Mandalika, Indonesia \\ ${ }^{4}$ Department of Physic Education, Universitas PGRI Madiun, Indonesia
}

\begin{tabular}{l}
\hline \hline Article Info \\
\hline Article history: \\
Received Dec 21, 2020 \\
Revised Jun 21, 2021 \\
Accepted Jul 19, 2021 \\
\hline
\end{tabular}

Keywords:

E-portfolio

Metacognitive

Project-based learning

\begin{abstract}
The present study aimed to investigate the metacognitive ability of students using e-portfolio assessment in project-based learning classes. The projects were a set out a critical analysis based on the selected references (project 1) and set out of field activities based on the selected theme content (project 2). Student metacognitive ability consists of three phases, planning, implementation, and evaluation abilities that were assessed through eportfolio assignments. There were 87 participants who divided into groups consisted of four to five students, conducted the projects, and submitted the progress of their projects in every decided step into online report assignments. The rubric of metacognition was used to acquire the quantitative score of skill that was separated into six levels category: not yet, at risk, not-really, developing, OK, and super. The result revealed that $44.83 \%$ of the students belong to the last three of those levels and the rest are otherwise. The lowest and highest metacognitive ability of the student is "not really" and "developing" respectively. Student metacognitive ability through conducting the project 2 activities is higher than project 1 . The findings showed that project-based learning (PBL) enables to foster the student metacognitive ability that developed through e-portfolio-based documents that student conducted during fulfilling all projects assignments.
\end{abstract}

This is an open access article under the $\underline{C C B Y-S A}$ license.

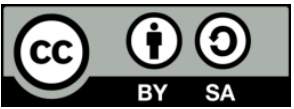

\section{Corresponding Author:}

Rusdi Hasan

Department of Biology Education

Universitas Muhammadiyah Bengkulu

Jalan Bali 118 Kota Bengkulu 38119, Indonesia

Email: rusdihasan@umb.ac.id

\section{INTRODUCTION}

Integration of metacognition that was supported using information and communication technology (ICT) beneficial for debriefing and improving students' literacy skill of information technology. ICT becomes an important part to possess for preparing the 21 st century generation [1]. Currently, the use of ICT, as a medium to support learning including the use of e-portfolio, is viewed as a potential way by many researchers in recent decades. An e-portfolio is "a digital container that capable of storing visual and auditory content including text, images, video and sound" [2]. The implementation of e-portfolios as an assessment tool to identify and reflect the students' ability as well as self-regulating learning ability has been widely reported across the discipline of science and ages [2]-[8]. It brings a different approach to generate the learning skills by using an e-portfolio, particularly, the activities of planning, implementing, and evaluating their study. 
The use of information technology especially the internet as the main learning resources is an important key to support the learning process to achieve the students' skills [9]. However, the support of ICT, especially in the educational field has not fully succeeded in expediting the process and in having a direct impact. There were cases that the support of the e-portfolio base has not shown significant results to support the student learning results [10]. Therefore, this condition challenges the educational practitioner and researcher to develop further and integrate e-portfolio to increase the students' motivation and metacognitive abilities [11], [12]. The application of technology in the form of e-portfolios in this study is designed based on metacognition, which is integrated into the learning projects. Metacognitive ability is required to practice active learning strategies that make students sensitive to their learning activities [13], [14] and that is reflected in their planning, implementing, and evaluating activities.

The learning strategy in science by using the project-based learning (PBL) model is widely applied to face the challenges of education in the 21 st century [15] such as the ability to solving problems, thinking critically, and working collaboratively. The student in the group to enable students to plan, implement and evaluate an assigned project carries out its implementation collaboratively. Some reports regarding the implementation PBL in learning showed that PBL was able to influence positively metacognition skills [16][18]. Implementing PBL in learning activities is often constrained by the lack of opportunity of students to gather in groups to discuss the project as well as the time necessity needed to complete the project [19], [20]. The problem regarding interaction intensity that is needed to complete projects can be reduced through the application of information, communication, and technology (ICT) [21] including using e-portfolios [22]. The application of e-portfolio-based PBL as the development of ICT requires the student to learn independently [23], [24] which is closely related to the ability of metacognition called planning, implementation and evaluation abilities.

The learning processes in the classroom that are only concerned with achieving learning outcomes in the cognitive and psychomotor domains often ignoring the importance of metacognitive abilities so that to raise the problem that leads to the students possess low ability to manage themselves to plan, implement and evaluate their learning. PBL provided a real experience that makes students capable to resolve the issues properly [25]. The use of ICT in the form of an e-portfolio, which is applied together with the PBL, has the potential to improve students' metacognition ability [6], [25], [26]. A critical component that needs to be considered so that learning becomes more effective is the students should be able to think and solve problems during the learning process [27]. E-portfolio provides a potential tool to improve 21st Century Skills especially in ICT [1] as well as the metacognitive ability [28] and should be integrated with the learning process [29]. E-portfolio potentially can make the documentation tasks system applied in each activity easier to carry out and the students' learning development to assess authentically. Previously we found that using eportfolio coupled with project-based learning improved the HOT's of students [22]. Therefore, this study was conducted to develop the student's metacognitive ability by taking advantage of e-portfolio assessment in project-based learning.

\section{RESEARCH METHOD}

\subsection{Participants}

The sample of this study was consisted of eighty-seven undergraduate students from three different classes belong to math, biology, and physic education study programs. The study was carried out during the odd semester of 3rd-year students in University of PGRI Madiun, Indonesia. Participants had to assign to the web-based e-portfolio tool that was developed.

\subsection{E-portfolio tool}

In this study, a particular website was used as an e-portfolio tool that specifically created to facilitate students' e-portfolio assignments and support social networking either between lecture and students or among students. The e-portfolio tool has a simple interface with some menus to make students can access the web easily. Students can communicate with each other or with the lecturer about their assignments and monitor their metacognitive achievement.

\subsection{Procedure}

This was descriptive research with 87 student participants that was conducted during the odd semester of 2016/2017. Before the research was started, the participants were introduced to learning strategy, metacognition, and e-portfolio base assignment to make them clear regarding the study role of play entirely. The participants of each class were grouped that consisted of four to five students to engage the project-based learning lecture and assign e-portfolio in fulfilling their project tasks that carried out both by group and individual. There were two projects that students must fulfill and reported through e-portfolio assignment. 
The first project was a set out of critical analytic of references on selected topics. The second project was the set out of field activities based on the selected theme content of the lecture. Every student must register to the e-portfolio tool to create their profile and submit their assignment or project activities and can access their group assignment. Students submitted a group assignment by one of the group members to the eportfolio tool. The group project plan was arranged and planned in the form of the layout which then was uploaded in the students' e-portfolio to obtain a suggestion from the lecturer as well as peers in the share column. The project plan which has been validated can be carried out by the group. The implementation progress of the project was then evaluated weekly by uploading the progress in the group's e-portfolio as well as through classroom presentation in every lecture. During the experiment, the student can interact with each other or with the lecturer through public or private messaging. The lecturer can monitor the student's assignments and activities and contact them through those same messaging. At the end of the research, participants completed the rubric of metacognition ability.

\subsection{Instrument}

In this research, the metacognition abilities were separated into three phases: planning, implementing, and evaluating. During carried out project assignment, we used the evaluation sheet to measure the student metacognitive abilities in every phase of metacognition ability. At the end of the research, a comprehension metacognitive ability was measured through the metacognitive test consisting of ten items of essay test. The scores were then categorized qualitatively according to the rubrics of metacognition [30]. There are six levels of metacognition: 1) Not yet (Not yet revealed/leads to metacognitive); 2) At-risk (Seems to have no awareness of thinking as a process); 3) Not really (Unable to separate what is thought from how he thinks); 4) Developing (Capable of awareness of self-thinking if encouraged and supported); 5) OK (Realize for own-thinking and able to distinguish the stages of his inputelaboration-output. Sometimes use models to regulate their thinking and learning); 6) Super (Use metacognitive awareness systematically to regulate the process of self-thinking and learning). Recognizing that there are many kinds of possibilities for thinking, being able to use them smoothly and reflect on the thinking process. The students completed the metacognitive ability test that integrated into the essay test after the project was carried out [31].

\subsection{Data analysis}

The data of student metacognition abilities were separated into six-level categories according to Amrulloh and Ardi [30], [31] as shown in Table 1. Thereafter, it was analyzed descriptively to describe the effect of the implementation of project-based learning with e-portfolio on students' metacognitive ability.

Table 1. The categories of student metacognitive ability

\begin{tabular}{cll}
\hline No & Score & Categories \\
\hline 1 & $0-16$ & Not yet \\
2 & $17-33$ & At-risk \\
3 & $34-50$ & Not really \\
4 & $51-67$ & Developing \\
5 & $68-84$ & OK \\
6 & $85-100$ & Super \\
\hline
\end{tabular}

\section{RESULTS AND DISCUSSION}

\subsection{Results}

Student groups carried out the assignment of two projects. Those are the set critical analytic of references on selected topics and field activities. During one semester of research, the data was collected base on an e-portfolio of the projects that they conducted by the group. Every student who belongs to each group can access the e-portfolio to review it either individually or within the group. The average metacognitive ability of students in every phase; planning, implementing, and evaluating are shown in Figure 1.

Student activities in conducting the project assignments reflect their metacognitive abilities of the student's group in every stage Figure 1. Student's group metacognitive abilities in planning, applying and evaluating during conducting project- 2 are relatively higher than those abilities in project- 1 . The average score of entire stages is increased from 64.02 with category 'developing' in project- 1 to 70.38 with category ' $\mathrm{OK}$ ' in project-2. At the applying and evaluating stages, the increase of scores meets the increase of level or category of metacognitive ability. Those are 66.78 to 69.42 and 56.2 to 72.41 for applying and evaluating stages, respectively. It increases from the category 'developing' to 'OK'. However, at the planning stage, there is only a slight increase of the score from 69.08 to 69.31 in project 1 and project 2 . Therefore, those increases can be ignored due possess the same category as "OK". 


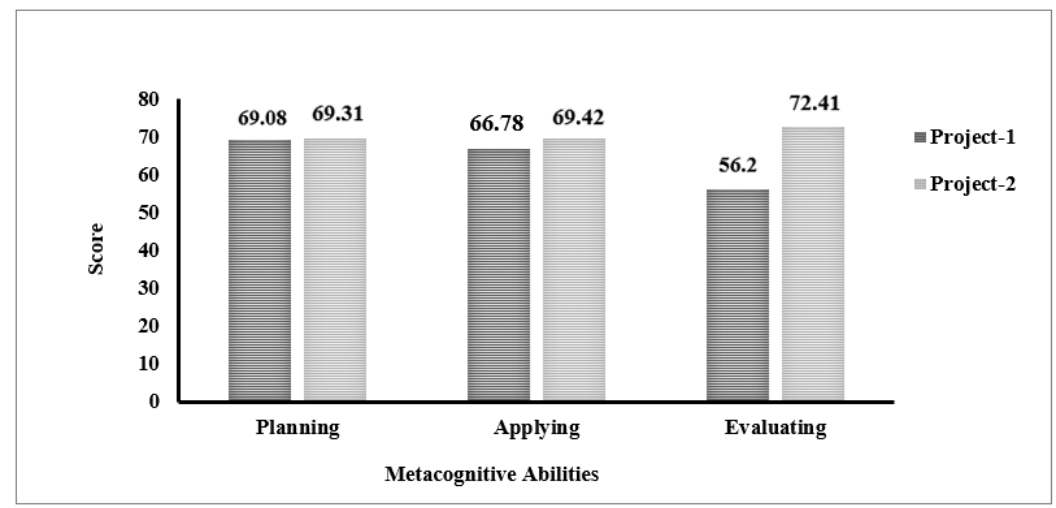

Figure 1. The score of the metacognitive ability of students group at three phases of metacognitive activities during carried out of the project- 1 and project- 2 assignments

In this study, to determine the metacognitive abilities of students individually, the students carried out the metacognitive assay test as the project assignment was finished at the end of the experiment. Table 2 shows the average of the metacognitive ability of students individually as well as its distribution among 87 students who participate in this experiment. Scores were clustered and categorized [31].

Table 2. Distribution of score of student's metacognitive ability at the project-based learning

\begin{tabular}{cccc}
\hline No & Score distribution & Frequency & Categories \\
\hline 1 & $0-16$ & 0 & Not yet \\
2 & $17-33$ & 18 & At risk \\
3 & $34-50$ & 20 & Not really \\
4 & $51-67$ & 31 & Developing \\
5 & $68-84$ & 8 & OK \\
6 & $85-100$ & 10 & Super \\
7 & Number of samples & 87 & - \\
8 & Mean & 54.67 & Developing \\
9 & Lowest score & 26 & At-risk \\
10 & Highest score & 100 & Super \\
11 & Range & 74 & - \\
\hline
\end{tabular}

Most students achieve metacognitive ability in three upper categories. They are 41 students or $56 \%$ who separated into 39\%, 9\% and 12\% of 'Developing', 'OK' and 'Super' categories, respectively. Although no one of the students who gain metacognitive score in the category 'Not yet', the number of students with the score inside the three lowest categories is relatively high. They are 37 students or $44 \%$ among 87 students. The lowest score is 26 in the category 'At risk' and the highest is 100 in the category 'Super'. Since the greatest number of students located in the middle cluster of metacognitive ability level and the range between the lowest and highest score is large, it cost the average achievement of metacognitive ability among 87 students to place the category 'Developing'.

\subsection{Discussion}

The use of an e-portfolio brings an improvement for students to develop metacognitive ability especially in implementing as well as evaluating. In each phase of the projects, students actively discuss their project development with the lecturers as well as their peers to obtain success. E-portfolio has some benefits especially in terms of sharing some information related to the source of learning among students [6], [11], [32]. On the other hand, the discussion process leads the collaboration among students during the implementation of the project plays an important role in the students' success. Once the students found any information source, they analyze it to find its relevance with their project matter. The development of student metacognitive ability collectively in the group showed the improvement, from 'developing' to 'OK' criteria. This indication showed that the use of e-portfolio helped the students to know and to realize their ability. It leads the student to do better in engaging the next phase of the project or the next project task. The students conducted the project activity gradually started from the plan, implementation, and evaluation, integrated with the e-portfolio assignment to facilitate in completing the project tasks. It affects the improvement of student project value they generated. This condition prompts a significant relationship between the 
development of metacognitive skills and academic ability [33]-[35]. Susantini, Indana, and Isnawati [36] used metacognitive as a learning strategy in pre-service teachers. This strategy showed that the high students' metacognitive abilities in correlation to their learning strategy knowledge. That result in correlation with our study due to once the students were given a challenge through project task and they felt capable to complete, it boosted huge motivation and confidence. The completion of the task through an e-portfolio allows the student to control and evaluate the task by either themselves or peers as well as lecturers. Through discussion sessions, the students could increase their motivation to complete the task and shall significantly affect the students' metacognitive ability. Amrai et al. [37] showed that motivation in learning which can be given through structured tasks were able to develop students' metacognitive ability. This means that one important point to develop metacognition is through continuously motivating students while improving the supporting facilities and planning the precise task in teaching-learning processes.

Of the three phases, the implementing and evaluating phases only contributed to this improvement, while none for the planning phase. However, the planning phase in project-1 has the highest score (69.08) compared to either applying (66.78) or evaluating (56.20) phase. Although there was no increase for the planning phase from project-1 to project-2, its metacognition ability has been at a good level i.e., the ' $O K$ ' category. The weakness of student's metacognitive ability of project-1 was at both applying and evaluating phases. The reasons were the fluency of students in carrying out of project task based on the metacognitive framework. In conducting and completing the project, the group of students still require assistance and active coordination from both friends and lecturers. Thus, it affected the metacognitive ability in applying and evaluating phases that only gained the 'developing' level. The fact appeared at the beginning of the project that the student likely faced difficulty in using the tool. Their focus was divided between applying the planning of the project and figuring out how to use the e-portfolio for their project which can be assumed as a new media for them. The students need at least two weeks to get used to the media. This thought was strengthened by either the score achievement of applying and evaluation phases in project- 2 that increases significantly compared to the score in the same phases of project- 1 or relatively to the planning phase in project-2 (Figure 1). Metacognitive abilities improvement of student can meet the expectation by the time and experience to use the tool comfortably for both students [38]. Although the planning phase of project-2 has the lowest score than other phases of the same project, all of them to place in the same category ' $O K$ '. Based on these results, it is expected that all phases of metacognitive abilities will increase as the students carry out more projects. Using e-portfolio assessment continuously especially in project-based learning strongly suggested will improve student metacognition abilities.

E-portfolio assessment is a very useful tool in supporting students to carry out the projects that conform to their needs, especially with the availability of messaging or chat board to facilitate their feedback. The chat feature in the e-portfolio supports the development of metacognitive ability, particularly in the improvement of applying and evaluating phases of project-2 through constructive discussion and consultation. Metacognitive strategy application has been shown to enable the improvement of motivation and academic achievement in a broad range of learning subjects and schools [39], [40]. Hence, the contribution of e-portfolio in improving metacognitive abilities in turn positively will improve student's academic achievement. The relevant use of e-portfolios in developing metacognitive skills indicates its potential to be implemented in a learning plan [6], [34]. Completing an e-portfolio allows the student to possess a higher metacognition ability level due to it contributes positively to the student's learning that provides a valuable reflection on their learning throughout the course [29]. E-portfolio admits the student to optimize their reflection and inquiry by delivering questions of themselves about the process and achievement of their ongoing or finished work in the learning to deliberate their comprehension [4].

The implementation of e-portfolios in project-based learning improved the score of the evaluation stage in project-2 significantly (Figure 1). It was accomplished gradually through the evaluation of every suggestion that came from both peers and lecturers. Mutual communication in evaluating their task can trigger to elevate critical thinking of the student and to find the solution of the problem they face. Some important points to be considered are writing and data collection technique, as well as the construction of the analytical result, which can be worked out accordingly. The learning activity through e-portfolio provides unlimited space of time to enable students to communicate anytime even though the lecturers must remind them occasionally. Through this project, students can do the "analysis" and "synthesis" of the project. Building capacity concerning analysis and synthesis as a hallmark of academic understanding which has been developed is an indication that students' metacognitive skills have increased. The condition can be explained through the link between academic and metacognitive skills [14], [41].

The average score that determines the level of metacognitive ability of students individually unlikely to place at the same level of that ability as performed by the group during the experiment was taking place. The level of metacognitive ability during the experiment that represents group ability was categorized 'OK' (70.38) in project-2 and was higher than the ability that represents the students individually with the 
category 'developing' (54.67). This result confirms that the level of group ability does not directly mirror the ability of each student individually. The difference may due to the collaboration among students within the group did not well established yet which impact the unequal responsibility and motivation among members of the group during both conducted the project and submitted the assignment into e-portfolio. Besides, the entire membership of the group did not have the same academic competency and intrinsic motivation as the group had.

Therefore, the level of metacognitive ability represented by the group during conducted the project did not exactly have the level, even higher than students performed individually at the end of this experiment. Cooperative learning admits learning proses to apply moral value such as respect, responsibility, and collaboration among students so that elevates their motivation to study [42]. Students who collaboratively learning in the group showed the improvement of their motivation and task as a positive impact of peer's support during the learning process that encouraging greater intrinsic consideration to perform and carried out the tasks [43] hence effective to improve their achievement [42], [44]. The more learning experience and the more amount of skill and fact as well lead to the better outcome of student achievement in project-based learning [24].

Some of the previous findings reveal the results shown regarding the use of e-portfolios in learning. Although there was a report stating that the implementation of e-portfolios did not provide significant results on improving student achievement in vocational education [10], several other findings indicated the positive results obtained from the use of e-portfolio that were applied with an approach or learning model such as in increasing of higher-order thinking skills [22], integrated learning [4], self-regulated learning [39]. In this study, we found that the application of e-portfolio in project-based learning improves the metacognitive skills of the student.

Using an e-portfolio as a base-learning model enables to foster the metacognitive abilities development [4] and positively improve self-regulating of students through its contribution in changing their motivation and learning strategy [45]. Using an e-portfolio in this study provides the student to access their project activities they documented wherever and whenever they want. It allows students the flexible time to analyze and to make the reflection of the project of their learning concerning their goal [29]. The reflection through e-portfolio allows students enable to review their current progress and evaluate the acquisition of their skills, as well as to improve students' ability to achieve higher-order thinking skills [46] and hence improving their metacognitive abilities. The unequal responsibility and motivation among students in the group caused that only some members of the group who either actively carry out the project or evolved in submitting, communicating, and reviewing their e-portfolio assignments. The remaining less active members of the group presumed that another member of the group has represented their project task, and so that they thought, their tasks and responsibilities have been fulfilled. The finding in which the student's group can perform the better ability of metacognitive affirm that learning process that conducted collaboratively in the group is more effective to resolve the problems or assignment they face during lecture. Strengthening a learning strategy in using e-portfolio assessment will be an interesting challenge to conduct that involves all students individually with equal responsibility to develop better and precisely mirroring abilities of metacognitive among students in-group and individually.

\section{CONCLUSION}

The results of the study provide information that the use of project-based e-portfolios that is applied through learning processes shows that students' metacognitive abilities develop better. During the learning activities, $56 \%$ of students reached the top category in development metacognition, and $44 \%$ of the others are in a low category. The applied e-portfolio can support students to be more active in planning project activities, discussing with groups and lecturers, implementing and evaluating the project. Metacognitive ability was measured based on planning, implementation, and evaluation activities of the group showed an improvement in project- 2 compared to project-1. There was a collaboration in online discussions through eportfolios that are not limited by place and are more time-efficient making the project results tend to be better than before. Look at the results of the research that the combination of implementing PBL using the eportfolio has strong potential to develop students' metacognitive abilities, especially for science learning. Although thus answering the challenges of the future still requires in-depth information about effectiveness, efficiency, and the complexity of choosing the use of learning strategies combined with technology so that it will help the development of student metacognition. Future research can examine variables such as student motivation, lecturer intervention, and other external variables that can affect e-portfolio use and the development of user metacognition. 


\section{ACKNOWLEDGEMENTS}

The authors' gratitude is given to Kemenristekdikti for the fund given to this research through Implementation of Technology funding, which enables the researchers to carry out the research. The second gratitude is given to the whole civic academic of Universitas PGRI Madiun as a place of research as well as the facilitator of the research.

\section{REFERENCES}

[1] N. Pheeraphan, "Enhancement of the 21st century skills for Thai higher education by integration of ICT in classroom," Procedia Soc. Behav. Sci., vol. 103, pp. 365-373, 2013, doi: 10.1016/j.sbspro.2013.10.346.

[2] P. C. Abrami and H. Barret, "Directions for research and development on electronic portfolios," Can. J. Learn. Technol., vol. 31, no. 3, pp. 1-7, 2005.

[3] A. Alexiou, F. Paraskeva, R. Enache, and A. Crisan, "Enhancing self-regulated learning skills through the implementation of an e-portfolio tool," Procedia Soc. Behav. Sci., vol. 2, pp. 3048-3054, 2010, doi: 10.1016/j.sbspro.2010.03.463.

[4] K. M. Anderson, P. Deslauriers, C. H. Horvath, M. Slota, and J. N. Farley, "From metacognition to practice cognition: The DNP e-portfolio to promote integrated learning," J. Nurs. Educ., vol. 56, no. 8, pp. 497-500, 2017, doi: 10.3928/01484834-20170712-09.

[5] R. Krys and S. E. Eaton, "Implementing the electronic portfolio: How to improve upper elementary student's metacognition," Werklund School of Education Working Papers, 2017, doi: 10.13140/RG.2.2.26592.69124.

[6] M. Lukitasari, H. Susilo, and A. D. Corebima, "Lesson study in improving the role of e-portfolio on the metacognitive skill and concept comprehension: A study on Cell Biology subject in IKIP PGRI Madiun, Indonesia," Am. J. Educ. Res., vol. 2, no. 10, pp. 919-924, 2014, doi: 10.12691/education-2-10-11.

[7] L. T. Nguyen and M. Ikeda, "The effects of ePortfolio-based learning model on student self- regulated learning," Act. Learn. High. Educ., vol. 16, no. 3, pp. 197-209, 2015, doi: 10.1177/1469787415589532.

[8] J. R. Chittum, "The theory-to-practice ePortfolio: An assignment to facilitate motivation and higher order thinking," Int. J. ePortfolio, vol. 8, no. 1, pp. 27-42, 2018.

[9] M. C. Sahin, "Instructional design principles for 21 st century learning skills," Procedia Soc. Behav. Sci., vol. 1, pp. 1464-1468, 2009, doi: 10.1016/j.sbspro.2009.01.258.

[10] W. Kicken, S. Brand-Gruwel, J. J. G. van Merrienboer, and W. Slot, "The effects of portfolio-based advice on the development of self-directed learning skills in secondary vocational education," Educ. Tech Res. Dev., vol. 57, no. 4, pp. 439-460, 2009, doi: 10.1007/s11423-009-9111-3.

[11] E. Meyer, P. C. Abrami, C. A. Wade, O. Aslan, and L. Deault, "Improving literacy and metacognition with electronic portfolios: Teaching and learning with ePEARL," Comput. Educ., vol. 55, no. 1, pp. 84-91, 2010, doi: 10.1016/j.compedu.2009.12.005.

[12] M. Farahian and F. Avarzamani, "The impact of portfolio on EFL learners' metacognition and writing performance," Cogent Educ., vol. 5, no. 1, pp. 1-21, 2018, doi: 10.1080/2331186X.2018.1450918.

[13] A. K. Ellis, D. W. Denton, and J. B. Bond, "An analysis of research on metacognitive teaching strategies," Procedia Soc. Behav. Sci., vol. 116, no. 2014, pp. 4015-4024, 2014, doi: 10.1016/j.sbspro.2014.01.883.

[14] T. A. Karsli, "Meta-cognition and locus of control in university students in context of viewpoint to rape," Procedia Soc. Behav. Sci., vol. 205, pp. 48-52, 2015, doi: 10.1016/j.sbspro.2015.09.010.

[15] F. Musa, N. Mufti, R. A. Latiff, and M. M. Amin, "Project-based learning (PjBL): inculcating soft skills in 21 century workplace," Procedia Soc. Behav. Sci., vol. 59, pp. 565-573, 2012, doi: 10.1016/j.sbspro.2012.09.315.

[16] F. Musa, N. Mufti, R. A. Latiff, and M. M. Amin, "Project-based Learning: promoting meaningful language learning for workplace skills," Procedia Soc. Behav. Sci., vol. 18, pp. 187-195, 2011, doi: 10.1016/j.sbspro.2011.05.027.

[17] M. Pavkov-Hrvojevic, D. Ž. Obadovic, S. Cvjeticanin, and I. Bogdanovic, "Fostering pimary school students' metacognition using project-based learning," Eurasia Proc. Educ. Soc. Sci., vol. 4, pp. 123-126, 2016.

[18] D. Rumahlatu and K. Sangur, "Implementation of project-based learning strategies to improve metacognitive skills and understanding of biodiversity concepts in state High School 2 Kairatu, West District of Seram," in Proceeding The 2nd International Seminar on Education, 2017, pp. 43-48.

[19] S. K. W. Chu, S. K. Tse, and K. Chow, "Using collaborative teaching and inquiry project-based learning to help primary school students develop information literacy and information skills," Libr. Inf. Sci. Res., vol. 33, pp. 132-143, 2011, doi: 10.1016/j.lisr.2010.07.017.

[20] J. W. Thomas, "A Review of research on project-based learning," The Autodesk Foundation, pp. 1-48, 2000.

[21] H. Heo, K. Y. Lim, and Y. Kim, "Exploratory study on the patterns of online interaction and knowledge coconstruction in project-based learning," Comput. Educ., vol. 55, no. 3, pp. 1383-1392, 2010, doi: 10.1016/j.compedu.2010.06.012.

[22] M. Lukitasari, J. Handhika, and W. Murtafiah, "Higher order thinking skills: using e-portfolio in project-based learning," J. Phys. Conf. Ser., vol. 983, no. 1, pp. 1-6, Apr. 2018, doi: 10.1088/1742-6596/983/1/012047.

[23] M. F. Ibrahim, et al., "Strengthening programming skills among engineering students through experiential learning based robotics project," Int. J. Eval. Res. Educ. (IJERE), vol. 9, no. 4, pp. 939-946, 2020, doi: 10.11591/ijere.v9i4.20653. 
[24] R. Pucher and M. Lehner, "Project based learning in computer science-A review of more than 500 projects," Procedia Soc. Behav. Sci., vol. 29, pp. 1561-1566, 2011, doi: 10.1016/j.sbspro.2011.11.398.

[25] G. Sart, "The effects of the development of metacognition on project-based learning," Procedia Soc. Behav. Sci., vol. 152, pp. 131-136, 2014, doi: 10.1016/j.sbspro.2014.09.169.

[26] N. Bozkurt, "An examination of the links between pre-service teachers' metacognitive level, learning styles and their achievement of History class," Procedia Soc. Behav. Sci., vol. 93, no. 2001, pp. 1634-1640, 2013, doi: 10.1016/j.sbspro.2013.10.093.

[27] C. Magno, "The role of metacognitive skills in developing critical thinking," Metacognition Learn., vol. 5, pp. 137-156, 2010, doi: 10.1007/s11409-010-9054-4.

[28] M. T. Cox, "Metacognition in computation: a selected research review," Artif. Intelegence, vol. 169, pp. 104-141, 2005, doi: 10.1016/j.artint.2005.10.009.

[29] J. Bowman, B. J. Lowe, K. Sabourin, C. S. Sweet, S. John, and F. College, "The use of ePortfolios to support metacognitive practice in a first-year writing program," Int. J. ePortfolio, vol. 6, no. 1, pp. 1-22, 2016.

[30] A. Amrulloh and M. W. Ardhi, "Identification of metacognition abilities in cell biology courses in biology education study program students," (in Bahasa), Prosiding Seminar Nasional SIMBIOSIS II, 2017, pp. 104-113.

[31] A. D. Corebima, "Metacognitive skill measurement integrated in achievement test," Paper presented at COSMED, RESCAM, Penang, Malaysia 2009.

[32] M. Lukitasari, R. Hasan, and A. Sukri, "The effect of e-portfolio on biological concepts understanding and responses of students with different academic achievement levels," Int. J. Instr., vol. 13, no. 1, pp. 685-694, 2020, doi: 10.29333/iji.2020.13144a.

[33] F. Gul and S. Shehzad, "Relationship between metacognition , goal orientation and academic achievement," Procedia Soc. Behav. Sci., vol. 47, pp. 1864-1868, 2012, doi: 10.1016/j.sbspro.2012.06.914.

[34] M. Hermita and W. P. Thamrin, "Metacognition toward academic self-efficacy among Indonesian private university scholarship students," Procedia Soc. Behav. Sci., vol. 171, pp. 1075-1080, 2015, doi: 10.1016/j.sbspro.2015.01.268.

[35] N. V. Dang, J. C. Chiang, H. M. Brown, and K. K. McDonald, "Curricular activities that promote metacognitive skills impact lower-performing students in an introductory Biology course," J. Microbiol. Biol. Educ., vol. 19, no. 1, pp. 1-9, 2018, doi: 10.1128/jmbe.v19i1.1324.

[36] E. Susantini, S. Indana, and Isnawati, "Using metacognitive strategy to teach learning strategies: A study of Indonesian pre-service biology teachers," New Educ. Rev., vol. 52, no. 2, pp. 258-268, 2018, doi: 10.15804/tner.2018.52.2.20.

[37] K. Amrai, S. E. Motlagh, H. A. H. Zalani, and H. Parhon, "The relationship between academic motivation and academic achievement students," Procedia Soc. Behav. Sci., vol. 15, pp. 399-402, 2011, doi: 10.1016/j.sbspro.2011.03.111.

[38] E. J. Meyer, P. C. Abrami, A. Wade, and R. Scherzer, "Electronic portfolios in the classroom: factors impacting teachers' integration of new technologies and new pedagogies," Technol. Pedagog. Educ., vol. 20, no. 2, pp. 191-207, 2011, doi: 10.1080/1475939X.2011.588415.

[39] C. Dignath and G. Büttner, "Components of fostering self-regulated learning among students. A meta-analysis on intervention studies at primary and secondary school level," Metacognition Learn., vol. 3, no. 3, pp. 231-264, 2008, doi: 10.1007/s11409-008-9029-x.

[40] C. Dignath, G. Buettner, and H. P. Langfeldt, "How can primary school students learn self-regulated learning strategies most effectively? A meta-analysis on self-regulation training programmes," Educ. Res. Rev., vol. 3, no. 2, pp. 101-129, 2008, doi: 10.1016/j.edurev.2008.02.003.

[41] G. Al-Baddareen, S. Ghaith, and M. Akour, "Self-efficacy, achievement goals, and metacognition as predicators of academic motivation," Procedia Soc. Behav. Sci., vol. 191, pp. 2068-2073, 2015, doi: 10.1016/j.sbspro.2015.04.345.

[42] Z. Mahamod and B. Somasundram, "Effectiveness of cooperative learning on the achievement and motivation of the student in learning Malay language," Creat. Educ., vol. 8, pp. 2438-2454, 2017, doi: 10.4236/ce.2017.815167.

[43] R. Enache and A. Crisan, "The impact of a collaborative learning using new informational technologies on personality development," Procedia Soc. Behav. Sci., vol. 76, pp. 327-335, 2013, doi: 10.1016/j.sbspro.2013.04.122.

[44] H. Husamah and Y. Pantiwati, "Cooperative learning STAD-PJBL: Motivation, thinking skills, and learning outcomes of biology department students," Int. J. Educ. Learn. Dev., vol. 2, no. 1, pp. 77-94, 2014.

[45] A. Alexiou and F. Paraskeva, "Enhancing self-regulated learning skills through the implementation of an eportfolio tool," Procedia Soc. Behav. Sci., vol. 2, pp. 3048-3054, 2010, doi: 10.1016/j.sbspro.2010.03.463.

[46] K. A. Parkes, K. S. Dredger, and D. Hicks, "E-Portfolio as a measure of reflective practice," Int. J. ePortoflio, vol. 3, no. 2, pp. 99-115, 2013, doi: 10.1177/1469787415589532. 